\title{
COMMENT: ALTERNATIVE CRIMINAL PENALTIES FOR WILFULLY FILING A FALSE INCOME TAX RETURN
}

\author{
Jacob Kossman $\dagger$
}

A seldom invoked principle of law has recently arisen, namely, that where identical offenses are punishable under two different statutes, the one carrying the lesser penalty governs.

In Berra v. United States ${ }^{1}$ the Supreme Court held that, in a prosecution under section 145 (b) of the Internal Revenue Code of $1939^{2}$ for wilfully attempting to evade federal income taxes by filing false and fraudulent returns, it was not error to refuse to instruct the jury, under rule 31(c) of the Federal Rules of Criminal Procedure, that a verdict of guilty of the "lesser crime" under section 3616 (a) ${ }^{8}$ of the same Internal Revenue Code would be permissible, for the reason that the latter was not a lesser included offense. The Court said:

"For here the method of evasion charged was the filing of a false return, and it is apparent that the facts necessary to prove that petitioner 'willfully' attempted to evade taxes by filing a false return $(\$ 145(\mathrm{~b}))$ were identical with those required to prove that he delivered a false return with 'intent' to evade taxes $(\S 3616(a))$. In this instance $\$ \oint 145(b)$ and 3616(a) covered precisely the same ground." 4

$\dagger$ Member, Philadelphia Bar.

1. 351 U.S. 131 (1956).

2. INT. REV. CoDE oF 1939, § 145(b) provided in part that: "Any person . . . who wilfully attempts in any manner to evade or defeat any tax imposed by this chapter or the payment thereof, shall, in addition to other penalties provided by law, be guilty of a felony and, upon conviction thereof, be fined not more than $\$ 10,000$, or imprisoned for not more than five years, or both, together with the costs of prosecution."

3. Id. $\$ 3616$ (a) provided in part that any person who "delivers or discloses to the collector or deputy any false or fraudulent ... return, .... with intent to defeat or evade the .... assessment intended to be made .... shall be fined not exceeding $\$ 1,000$, or be imprisoned not exceeding one year, or both, at the discretion of the court, with costs of prosecution."

The Berra case arose under the Internal Revenue Act of 1939. The sections involved have been changed in the 1954 Act. INT. REv. CoDE of 1954, $\$ \$ 7201,7207$. Significantly, as Justice Harlan noted, 351 U.S. at 132, § 7207 no longer requires the element of an attempt "to defeat or evade" taxes, as was so under the former $\$ 3616$ (a). Therefore, in all income tax cases that do not arise under the 1954 Act, where the statute of limitations has not run, the Government will probably if wise, now charge in its indictments affirmative acts such as "preparing" or "concealing," et cetera, and not simply "filing."

4. 351 U.S. at 134. 
And further:

"Here, whether $\$ 145(\mathrm{~b})$ or $\$ 3616(\mathrm{a})$ be deemed to govern, the factual issues to be submitted to the jury were the same; the instruction requested by petitioner would not have added any other such issue for the jury's determination. When the jury resolved those issues against petitioner, its function was exhausted, since there is here no statutory provision giving to the jury the right to determine the punishment to be imposed after the determination of guilt. Whatever other questions might have been raised as to the validity of petitioner's conviction and sentence, because of the assumed overlapping of $\$ \$ 145(\mathrm{~b})$ and $3616(\mathrm{a})$, were questions of law for the court. No such questions are presented here." 5

Justice Black, with whom Justice Douglas joined in a dissenting opinion, stated:

"The Government admits here and the Court assumes that filing a false and fraudulent income tax return is both a misdemeanor under $\$ 3616(\mathrm{a})$ and a felony under $\$ 145(\mathrm{~b})$. The Government argues that the action of the trial judge must be upheld because 'the Government may choose to invoke either applicable law,' and 'the prosecution may be for a felony even though the Government could have elected to prosecute for a misdemeanor.' Election by the Government of course means election by a prosecuting attorney or the Attorney General. I object to any such interpretation of $\$ \oint 145$ and 3616 . I think we should construe these sections so as not to place control over the liberty of citizens in the unreviewable discretion of one individual -a result which seems to me to be wholly incompatible with our system of justice. Since Congress has specifically made the conduct charged in the indictment a misdemeanor, I would not permit prosecution for a felony under the broad language of $\$ 145(\mathrm{~b})$. Criminal statutes, which forfeit life, liberty or property, should be construed narrowly, not broadly." 8

The majority of the Court did not consider the correctness of the sentence because it simply was never challenged. But it is clear that if the Government elects to charge a defendant with attempting to evade taxes by filing a false and fraudulent return, under such circumstances, sections 3616 (a) and 145 (b) cover the same ground ${ }^{7}$ and the defendant may be sentenced ${ }^{8}$ only on section $3616(a)$. There is no contention that either of the two sections involved impliedly

5. Id. at 134-35.

6. Id. at 138 .

7. The Government admitted in its brief in the Berra case that "the filing of a false and fraudulent return with intent to evade tax is also made a misdemeanor by Section $3616(a)$; and the section clearly applies to all federal tax returns, including income tax." Brief for Appellees, p. 23, Berra v. United States, 351 U.S. 131 (1956).

8. The trial court on its own motion reduced Berra's sentence from four years imprisonment to two years. 
repeals the other..$^{9}$ The mention of $145(b)$ in the indictment is, of course, of no significance. ${ }^{10}$

Furthermore, where the same subject matter is covered both by a general and special statute, the terms of the latter prevail.11 As Justice Van Devanter said in Washington v. Miller: ${ }^{12}$

"In these circumstances we think there was no implied repeal, and for these reasons: First, such repeals are not favored, and usually occur only where there is such an irreconcilable conflict between an earlier and a later statute that effect reasonably cannot be given to both . . . ; second, where there are two statutes upon the same subject, the earlier being special and the later general, the presumption is, in the absence of an express repeal, or an absolute incompatibility, that the special is intended to remain in force as an exception to the general . . . ; and, third, there was in this instance no irreconcilable conflict or absolute incompatibility, for both statutes could be given reasonable operation if the presumption just named were recognized." 13

In the present context this rule means that where a statute of general application prescribes a particular penalty, and a statute of special application prescribes a lesser penalty, the latter prevails.

Thus, in Robinson $v$. United States, ${ }^{14}$ the defendant had been convicted of larceny of money that was a part of the postal revenues.

9. Cf. United States v. Beacon Brass Co., 344 U.S. 43 (1952).

10. United States v. Hutcheson, 312 U.S. 219, 229 (1941); Williams v. United States, 168 U.S. 382, 389 (1897) ; United States v. Albanese, 224 F.2d 879, 881 (2d Cir.), cert. denied, 350 U.S. 845 (1955) ; FED. R. CRIM. P. 7c. If there were an omission or error in the citation of the statute invoked, obviously this would not be a ground for dismissal, since the indictment alone apprises the defendant of the charge. Therefore, the mere citation of $\S 145$ (b) alone is no authority for a sentence under $\$ 145$ (b) where the charge in the indictment charges an offense punishable equally under $\$ 145(\mathrm{~b})$ or $\$ 3616(\mathrm{a})$.

In its brief filed in Parr v. United States, 351 U.S. 513 (1956), the Government acknowledged that there was a fundamental distinction in an indictment charging an "attempt" by acts other than filing and one simply charging filing, stating: "Further, under the allegations of the first indictment in the Southern District the Government was required to prove affirmative acts of evasion independent of and in addition to proof that petitioner had wilfully filed a false income tax return at Austin. It is true, as the United States Attorney stated to Judge Kennerly, that the same witnesses would be used in proving the case under either indictment; but the extent of their testimony and the manner of their testifying and the quality of their evidence might not be of critical importance under the simpler proof involved in the second indictment." Brief for Appellees, p. 74, Parr v. United States, 351 U.S. 513 (1956). (Emphasis added.)

11. Clearly, the specific charge of filing a false return, which is spelled out en haec verba, $\$ 3616(\mathrm{a})$, prevails over the general denunciation of attempting to evade taxes prescribed by $\S 145(\mathrm{~b})$, wherein the filing of a false return is only one of the "attempts in any manner" and then not as a matter of specific statutory prohibition but by judicial interpretation, for the actual act of filing is not even an essential element of the offense under $\$ 145(\mathrm{~b})$, United States v. Albanese, supra note 10 , at 881 . In United States v. Demos, 291 Fed. 104 (S.D. Fla. 1923), the court expressed doubt whether Congress ever intended that the offense of evading or defeating an income tax established in an internal revenue act should cover the making of a false and fraudulent return, since that act was already punished under a prior statute.

12. 235 U.S. 422 (1914).

13. Id. at 428 .

14. 142 F.2d 431 (8th Cir. 1944). 
This was a special offense for which section 190 of the former Criminal Code prescribed a maximum sentence of not more than three years. But the punishment for stealing property of the United States generally was ten years, under section 46 of the Criminal Code. The court held that only the lesser punishment could be imposed, citing many federal cases, and saying:

"Elementally, the special stands against the general. That is, where there is a law against any stealing, and another and different law against stealing some particular thing, the two laws do not invalidate each other by conflict, but the courts treat the law against stealing the particular thing as presenting an exception to the law against stealing things in general. They enforce the exception. . . .

".

“. . . This rule is particularly applicable to criminal statutes in which the specific provisions relating to particular subjects carry smaller penalties than the general provisions." 15

In Bell v. United States ${ }^{16}$ the Court stated:

"When Congress leaves to the Judiciary the task of imputing to Congress an undeclared will, the ambiguity should be resolved in favor of lenity. And this not out of any sentimental consideration, or for want of sympathy with the purpose of Congress in prescribing evil or anti-social conduct. It may fairly be said to be a presupposition of our law to resolve doubts in the enforcement of a penal code against the imposition of a harsher punishment." 17

Since the identical offense is punishable under two different statutes, the one carrying the lesser penalty governs. ${ }^{18}$ If there is any ambiguity, the principle construing statutes in pari materia applies. And it is elementary that statutes that prescribe punishment for the same offense must be construed together, and if there is any doubt as to which penal clause is applicable, the defendant is entitled to the lesser penalty.

The Government's main contention in the Berra case, that "the Government may choose to invoke either applicable law," section 145 (b) or section $3616(a)$, and "the prosecution may be for a felony

15. Id. at 432 .

16. 349 U.S. 81 (1955).

17. Id. at 83 .

18. In United States v. Moran, 236 F.2d 361 (2d Cir. 1956), the Court of Appeals for the Second Circuit, on August 15, 1956, ignored this principle and remarked simply that ". . . each section requires an element of proof not required by the other." Id. at 363. This, however, disregards the dominant fact that the charge in the indictmentthe filing of a false and fraudulent return-does not require different elements of proof. As the Supreme Court stated in the Berra case: "In this instance $\S \S 145$ (b) and 3616 (a) cover precisely the same ground." 351 U.S. at 134.

The Moran decision was questioned five days later by Judge Jerome Frank in United States v. H.J.K. Theatre Corporation, 236 F.2d 502 (2d Cir. 1956). 
even though the Government could have elected to prosecute for a misdemeanor," is surely not equal justice under the law. While the Constitution does not require that a law should affect all persons exactly alike, there is a guarantee of like treatment to all persons similarly situated.

If a defendant can be indicted on the same state of facts for either a felony or a misdemeanor, it would follow that a grand jury or the United States Attorney, or both together, would have uncontrolled power to say how a person filing a false income tax return shall be prosecuted and punished.

In the Berra case Justice Black, in his opinion concurred in by Justice Douglas, said in this respect:

"A basic principle of our criminal law is that the Government only prosecutes people for crimes under statutes passed by Congress which fairly and clearly define the conduct made criminal and the punishment which can be administered. This basic principle is flouted if either of these statutes can be selected as the controlling law at the whim of the prosecuting attorney or the Attorney General." 19

The line is not drawn according to the amount of unreported tax or on the basis of whether the surrounding circumstances indicate matter in aggravation or in mitigation. The prosecutor and the grand jury would be permitted to determine the gravity of criminal charges and consequent punishment solely upon the basis of whim, caprice or upon their estimate of a defendant's social desirability as an individual. Any such delegation of power would, it is submitted, be plainly unconstitutional. Justice Black expressed this concept in the Berra case as follows:

"A congressional delegation of such vast power to the prosecuting department would raise serious constitutional questions. Of course it is true that under our system Congress may vest the judge and jury with broad power to say how much punishment shall be imposed for a particular offense. But it is quite different to vest such powers in a prosecuting attorney. A judge and jury act under procedural rules carefully prescribed to protect the liberty of the individual. Their judgments and verdicts are reached after a public trial in which a defendant has the right to be represented by an attorney. No such protections are thrown around decisions by a prosecuting attorney. Substitution of the prosecutor's caprice for the adjudicatory process is an action I am not willing to atribute to Congress in the absence of clear command. Our system of justice rests on the conception of impersonality in the criminal law." 20 
Whatever justification there may be for imposing more severe penalties for the same offense on persons who previously have been convicted of crime, ${ }^{21}$ no justification can be found for giving power to prosecutors to make a selection among defendants in criminal cases based on no standards defined by law.

In two recent, well-reasoned cases in the Supreme Court of Oregon, such delegation of power, even though specifically provided for by statute, was held unconstitutional. In State v. Pirkey, ${ }^{22}$ an Oregon statute delegated to the grand jury or to the committing magistrate power to determine in advance whether to charge a defendant with felony or misdemeanor for issuing a check with insufficient funds in the bank with which to pay such check. No standards for the exercise of the discretion conferred were set forth in the statute.

The Supreme Court of Oregon held the measure unconstitutional, saying:

"It would be monstrous to uphold and enforce a statute which authorized a grand jury or magistrate to determine finally whether an accused should receive a fine or a jail sentence, on the one hand, or a penitentiary sentence, on the other, and to make that decision before trial, without having heard any evidence from the defendant, either on the issue of guilt or of mitigation, and on the sole basis of a prima facie case made against one still presumed to be innocent . . . We see in this statute no provision whereby one charged with a misdemeanor could be sentenced as for a felony, however heinous the offense might after trial appear to have been. Again, if the defendant is proceeded against as for and convicted of a felony, there is no provision authorizing the court in its informed discretion to impose punishment as for a misdemeanor, however strong the evidence in mitigation might be. In our opinion, such a statute so construed would not only violate the Equal Protection Clause and constitute an unauthorized delegation of discretionary power, but it would constitute an invalid encroachment upon the function of the courts whose prerogative and duty it is to determine, not only guilt, but punishment, upon judicial inquiry, after public trial and within the maximum and minimum limitations prescribed by the legislature." 23

Furthermore, the court continued:

"It might be said that this statute classifies punishments but does not classify the circumstances to which the diverse punish-

21. In this regard, see Pennsylvania v. Ashe, 302 U.S. 51 (1937).

22. 203 Ore. 697, 281 P.2d 698 (1955).

23. Id. at 706, 281 P.2d at 702-03. 
ments are to be applied. This is not legal classification. It is legal chaos." 24

And in State $v$. Cory, ${ }^{25}$ the same court struck down a similar statute for the same reason.

The foregoing two decisions construed the equal protection clause of the fourteenth amendment, which of course binds only the states. But the same concept of unjustifiable discrimination offends equally against the due process clause of the fifth amendment that is operative against the United States. ${ }^{26}$

Consequently, by parity of reasoning, any such unbridled discretion in a United States Attorney and a federal grand jury to determine whether the precise act shall be deemed a felony under section 145 (b) or a misdemeanor under section 3616 (a) would offend against due process of law.

However, the constitutional issue is avoided by application of the well-settled rule first discussed herein, namely, that where the same offense is covered both by a general and specific statute, and no different proof is required, the terms of the specific prevail, particularly where the punishment is less.

The constitutional problem posed by the unlimited and uncanalized discretion lodged in the prosecutor and the accusatory body to determine whether an identical act shall be deemed felony or misdemeanor nonetheless requires that where an indictment charges an offense that is punishable either as a felony or a misdemeanor, it must be considered a misdemeanor only; the specific offense denounced by section 3616 (a) prevails over the catalogue of offenses ${ }^{27}$ that falls within the ambit of section 145 (b).

It is no answer that the Government might have spelled out affirmative acts other than "filing." 28 "The rule that a man should not be charged with one crime and convicted of another" was long ago applied in Chief Justice Marshall's time. ${ }^{29}$ The Supreme Court did not reject this principle in the Berra case. It merely postponed its application.

This much is certain, today the constitutional guarantees controlling administration of criminal punishment retain an effectiveness commensurate with their fundamental importance.

24. Id. at $705,281 \mathrm{P} .2 \mathrm{~d}$ at 702 .

25. 204 Ore. 235, 282 P.2d 1054 (1955).

26. Bolling v. Sharpe, 347 U.S. 497, 499 (1954).

27. Cf. Spies v. United States, 317 U.S. 492, 499 (1943).

28. See Cole v. Arkansas, 333 U.S. 196 (1948).

29. Schooner Hoppet v. United States, 11 U.S. (7 Cranch) 389, 394 (1813). 